\title{
Case Study: High Efficiency Dehumidification System (HEDS) Performance Modeling
}

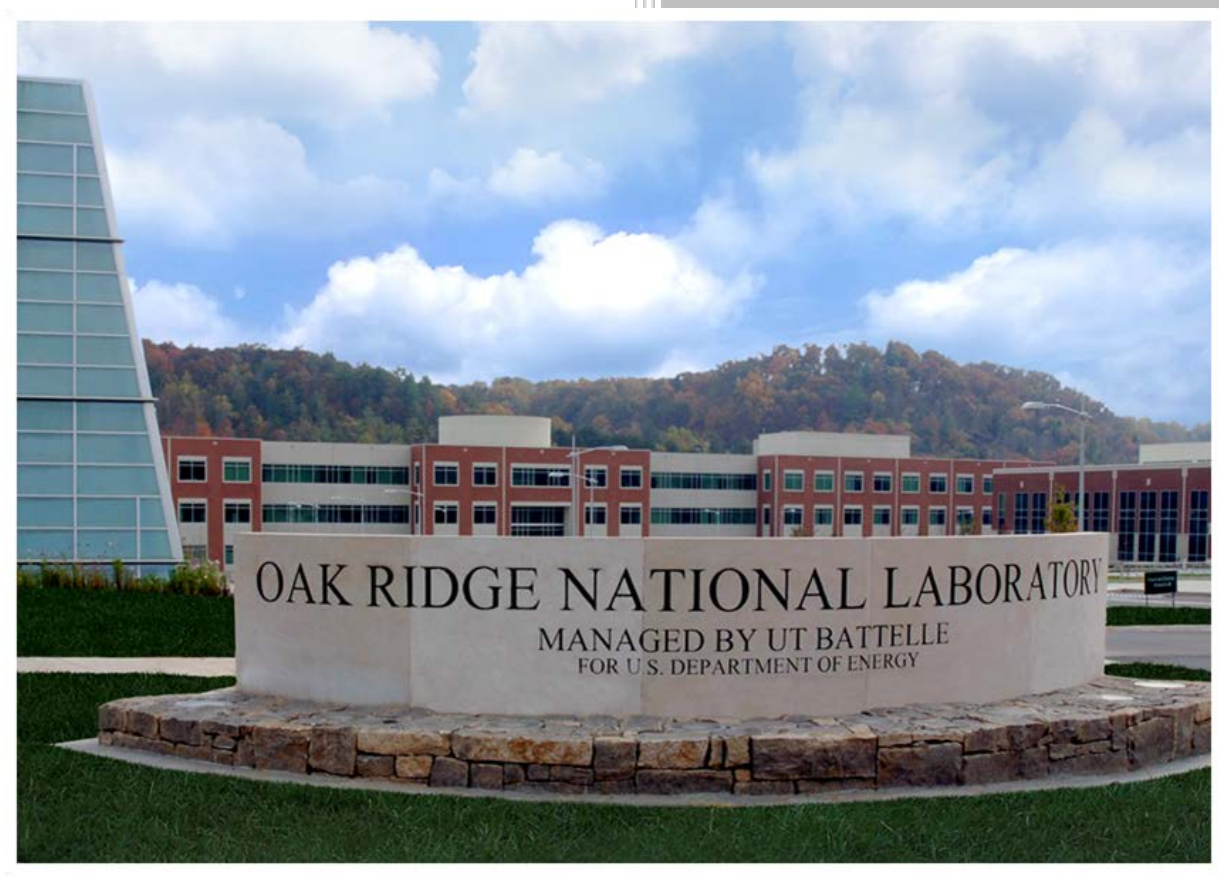

Approved for public release. Distribution is unlimited. 


\title{
DOCUMENT AVAILABILITY
}

Reports produced after January 1, 1996, are generally available free via US Department of Energy (DOE) SciTech Connect.

\section{Website http://www.osti.gov/scitech/}

Reports produced before January 1, 1996, may be purchased by members of the public from the following source:

\author{
National Technical Information Service \\ 5285 Port Royal Road \\ Springfield, VA 22161 \\ Telephone 703-605-6000 (1-800-553-6847) \\ TDD 703-487-4639 \\ Fax 703-605-6900 \\ E-mail info@ntis.gov \\ Website http://classic.ntis.gov/
}

Reports are available to DOE employees, DOE contractors, Energy Technology Data Exchange representatives, and International Nuclear Information System representatives from the following source:

Office of Scientific and Technical Information

PO Box 62

Oak Ridge, TN 37831

Telephone 865-576-8401

Fax 865-576-5728

E-mail reports@osti.gov

Website http://www.osti.gov/contact.html

This report was prepared as an account of work sponsored by an agency of the United States Government. Neither the United States Government nor any agency thereof, nor any of their employees, makes any warranty, express or implied, or assumes any legal liability or responsibility for the accuracy, completeness, or usefulness of any information, apparatus, product, or process disclosed, or represents that its use would not infringe privately owned rights. Reference herein to any specific commercial product, process, or service by trade name, trademark, manufacturer, or otherwise, does not necessarily constitute or imply its endorsement, recommendation, or favoring by the United States Government or any agency thereof. The views and opinions of authors expressed herein do not necessarily state or reflect those of the United States Government or any agency thereof. 


\section{Energy \& Transportation Science Division}

CASE STUDY:

HIGH EFFICIENCY DEHUMIDIFICATION SYSTEM (HEDS) PERFORMANCE MODELING

Date Published: June 2018

Prepared by

OAK RIDGE NATIONAL LABORATORY

Oak Ridge, TN 37831-6283

managed by

UT-BATTELLE, LLC

for the

US DEPARTMENT OF ENERGY

under contract DE-AC05-00OR22725 



\section{Contents}

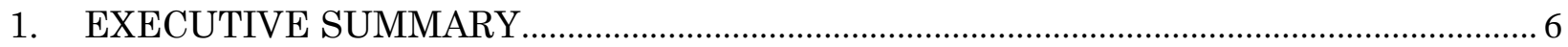

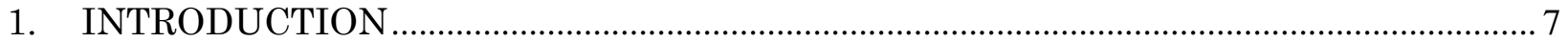

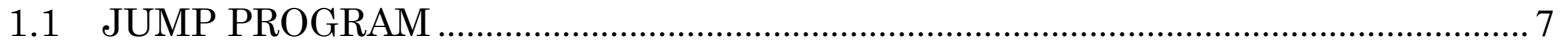

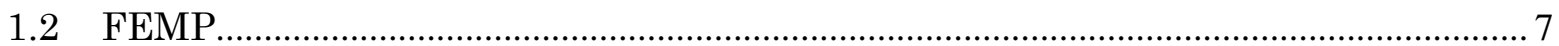

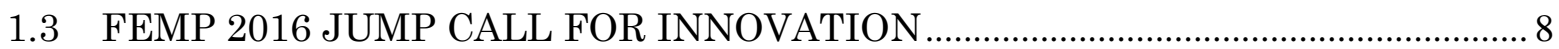

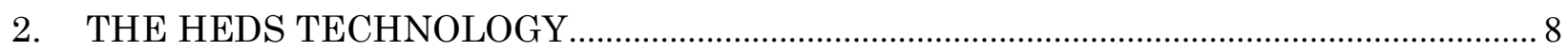

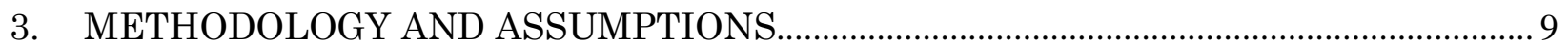

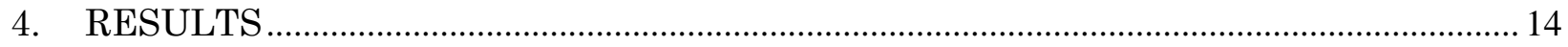

4.1.1 Energy savings analysis for Fort Bragg - HEDS with retrofit chiller ........ 15

4.1.2 Energy savings analysis for Fort Bragg - HEDS with basecase chiller...... 15

4.1.3 Energy savings analysis for Miami - HEDS with retrofit chiller.................. 16

4.1.4 Energy savings analysis for Miami - HEDS with basecase chiller.............. 19

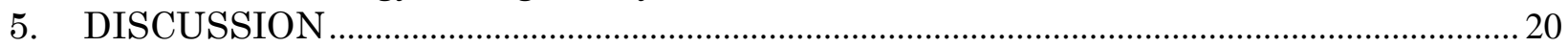

\section{Figures}

Figure 1: Conventional Reheat Dehumidification, figure courtesy of ROI............................................... 9

Figure 2: High Efficiency Dehumidification System (HEDS), figure courtesy of ROI. ............................. 10

Figure 3: Air-side pressure drop vs. flow depth................................................................................... 12

Figure 4: Monthly ambient temperature and relative humidity, Fort Bragg Simmons Field........................ 15

Figure 5: Comparison of energy consumption for conventional system and HEDS, Fort Bragg ................ 15

Figure 6: Monthly chiller energy consumption for cooling months, Fort Bragg ....................................... 13

Figure 7: Monthly fan energy consumption for cooling months, Fort Bragg .............................................. 13

Figure 8: Coil Water Temperatures and space RH for a peak day at Fort Bragg ....................................... 14

Figure 9: Monthly total HVAC energy consumption for Fort Bragg .......................................................... 14

Figure 10: Comparison of HVAC energy consumption, retrofit case Fort Bragg ........................................ 15

Figure 11: Monthly chiller energy consumption for cooling months, retrofit case Fort Bragg ................... 15

Figure 12: Monthly ambient dry bulb temperature and RH for Miami ...................................................... 16

Figure 13: Comparison of energy consumption for cooling months, Miami................................................ 16

Figure 14: Monthly chiller energy consumption for cooling months, Miami...........................................17

Figure 15: Monthly fan energy consumption for cooling months, Miami...............................................17

Figure 16: Coil temperatures and space RH for HEDS on a peak day (July 21) for Miami.......................18

Figure 17: Monthly total HVAC energy consumption for Apr-Sept, Miami............................................... 18

Figure 18: Comparison of energy consumption for cooling months for a retrofit case, Miami ................... 19

Figure 19: Monthly chiller energy consumption for cooling months for a retrofit case, Miami ................. 19

\section{Tables}

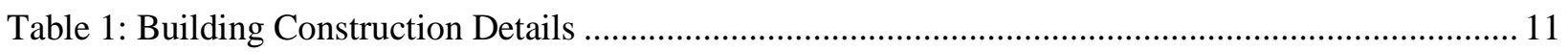

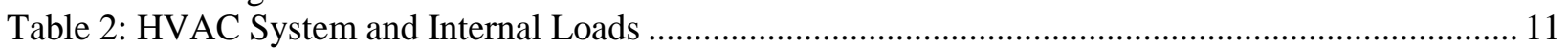

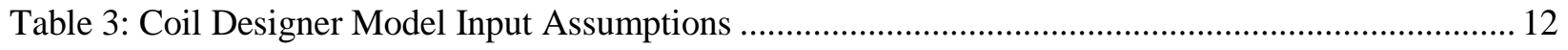




\section{EXECUTIVE SUMMARY}

This report summarizes an energy modeling analysis of a novel approach to air handler cooling, dehumidification and reheat. As part of the DOE JUMP crowdsourcing campaign for building energy efficiency technologies, applicants were invited to submit new technology ideas for consideration. After review by a panel of experts and voting by attendees at the 2016 Federal Energy Exchange, Retrofit Originality Inc's technology - the High Efficiency Dehumidification System (HEDS), was selected as the JUMP winner of the Federal Energy Management Program (FEMP) call for innovation. FEMP then funded staff at Oak Ridge National Laboratory to analyze the technology. EnergyPlus modeling was conducted to evaluate the HEDS potential performance in a typical building. For comparison purposes, the model was evaluated at two different high-humidity climate zone locations. The modeling results show that the HEDS could produce 16\%-49\% HVAC energy savings depending on climate and whether the installation involves only a HEDS unit or if a reduction in chiller capacity is made at the same time. This analysis did not include an evaluation of financial performance (e.g. energy cost savings, first cost impact, simple payback, and return-on-investment). This modeling evaluation also did not address potential challenges to commercial feasibility and integration challenges such as larger air handler footprints. 


\section{INTRODUCTION}

\subsection{JUMP PROGRAM}

The JUMP program is a technology crowdsourcing campaign developed by Oak Ridge National Laboratory (ORNL) and funded by the U.S. Department of Energy Building Technologies Office (DOE BTO).

JUMP stands for:

Join the Discussion

Unveil Innovation

Motivate Transformation

Promote Tech to Market

JUMP connects innovators with industry partners to help bring new energy saving technologies to market. ORNL works with industry sponsors to develop calls for innovation that describe a technical challenge. The public and private sector businesses are then invited to submit their technology ideas to the JUMP program using an online interface by IdeaScale. Interested parties are encouraged to join the IdeaScale online community and to discuss technologies and to vote on them. A panel of technical experts then evaluates the idea submissions and, if a promising idea is identified, a JUMP winner is announced. In addition to the recognition given to the innovator by the JUMP program, typically the industry sponsor of the innovation call offers a monetary award. The industry sponsor and award winner then work together to refine the technology and further it towards the market. Since 2015 the JUMP program has included participation from a total of five national laboratories and fifteen industry sponsors in sixteen calls for innovation. The calls for innovation have engaged 1,446 online community members on 215 idea submissions. Seventy six percent of the businesses submitting ideas were small businesses.

\subsection{FEMP}

The Federal Energy Management Program (FEMP) is part of the Office of Energy Efficiency and Renewable Energy (EERE) at the U.S. Department of Energy. FEMP works with its stakeholders to enable federal agencies to meet energy-related goals, identify affordable solutions, facilitate public private partnership, and provide energy leadership to the country by identifying and leveraging government best practices. FEMP provides extensive training and technical assistance to agencies as well as guidance on federal energy efficiency compliance and reporting. This includes contracting and technical assistance with alternative energy efficiency approaches such as energy savings performance contracts (ESPCs) and utility energy service contracts (UESCs). FEMP also provides technical and contracting information on energy efficient products and guidance on implementing energy efficiency and resiliency in federal buildings and campuses. 


\subsection{FEMP 2016 JUMP CALL FOR INNOVATION}

In June 2016, a JUMP Call for Innovation sponsored by FEMP was announced by EERE. The technology call was focused on lighting, lighting controls, packaged Heating Ventilating and Air-Conditioning (HVAC) systems and HVAC control systems. In a departure from the traditional JUMP evaluation process, a group of finalists was identified by the FEMP review panel. Three finalists were then invited to present their ideas in Providence, Rhode Island at the 2016 FEMP Energy Exchange conference. Energy Exchange is FEMP's annual flagship training event for the federal energy management community. The conference typically draws more than 2,500 attendees from government and private sector to discuss best practices for energy management as it pertains to federal installations. The conference includes a wide variety of training sessions (on both technical and contracting issues) as well as a tradeshow.

The three finalists presented their technology ideas during a scheduled Energy Exchange session titled "Solutions for the Federal Sector" in the tradeshow technology theater. Audience members were then asked to vote on which technology idea they felt had the most potential for federal agency applications and a federal panel considered those votes in their selection of the winner. The technology idea winner was Retrofit Originality Inc.'s HighEfficiency Dehumidification System (HEDS). Retrofit Originality (ROI) was recognized as the JUMP award winner by FEMP Program Director Dr. Timothy Unruh at the Energy Exchange closing plenary session. As part of the JUMP award, FEMP provided funding to ORNL to analyze the technology for potential energy savings in the federal buildings sector.

\section{THE HEDS TECHNOLOGY}

ROI's HEDS technology is an innovative approach to dehumidification and space conditioning. Traditionally dehumidification in large HVAC systems has often been accomplished by condensing water vapor from the airstream as it passes over a cooling coil. To condense enough water from the air to control relative humidity $(\mathrm{RH})$ in the space, the leaving air temperature is typically lower than the temperature required for cooling the space. To avoid subcooling the conditioned space below setpoint and unintentionally increasing the relative humidity of the space, it is necessary to reheat the subcooled airstream using a separate heating coil (generally a hot water coil or electric heating coil). This cool, dry leaving air is then suitable for cooling and dehumidifying the conditioned space. Other conventional dehumidification systems used in air handlers may include dedicated run-around coils (required upstream and downstream of the cooling coil), heat pipe coils, air-to-air heat exchangers and rotary heat wheels (some of which may have desiccant materials that require energy for regeneration).

The HEDS approach uses a coil with a much larger face area and extended depth to cool the airstream. Next a second coil, referred to as the Cooling Recovery Coil (CRC), is used to temper the cooled air back up to a temperature suitable for satisfying the conditioned space's cooling load. The CRC is fed by the water leaving the cooling coil rather than being supplied by an external heat supply such as a boiler. The HEDS design is intended to reduce chiller and boiler plant loads. In addition, by using coils with larger face areas, the 
fan load (in terms of static pressure) is reduced as the larger coil yields a much lower air pressure drop.

\section{METHODOLOGY AND ASSUMPTIONS}

A simplified energy savings potential analysis was carried out for a 10,000-sf building. The size corresponds to 10,000 CFM supply air being used in the earlier DOE ESTCP HEDS field demonstration at Fort Bragg. It is to be noted that due to the unavailability of all the input and measured data required for a complete model calibration, no calibration modeling was done (i.e. the simulation output was not compared with the measured data at Fort Bragg).

A rectangular building with floor area of $10,000 \mathrm{ft}^{2}$ and daytime occupancy was simulated to determine the energy savings potential of HEDS. The construction parameters used are provided in Table 1. Figure 1 and Figure 2 (provided by ROI) depict the conventional and HEDS system arrangement that was used for modeling. For each climate zone location, two different whole building energy models were created in the EnergyPlus to analyze the energy savings potential of HEDS as compared to the conventional case.

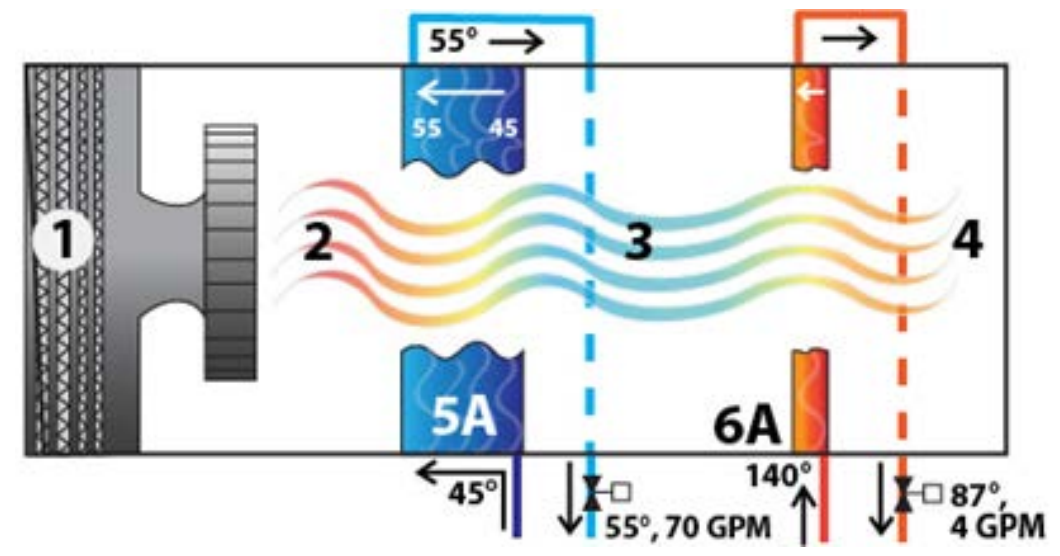

Figure 1: Conventional Reheat Dehumidification, figure courtesy of ROI.

[Data Points 1 thru 4: [1] 10,000 CFM airflow [2] $78^{\circ} \mathrm{F}$ dry bulb temp, $65^{\circ} \mathrm{F}$ wet bulb temp [3] $55^{\circ} \mathrm{F}$ dry bulb, $55^{\circ} \mathrm{F}$ dewpoint, essentially $100 \%$ relative humidity [4] $65.3^{\circ} \mathrm{F}$ dry bulb, $55^{\circ} \mathrm{F}$ dewpoint, $\left.55 \% \mathrm{RH}\right]$ 


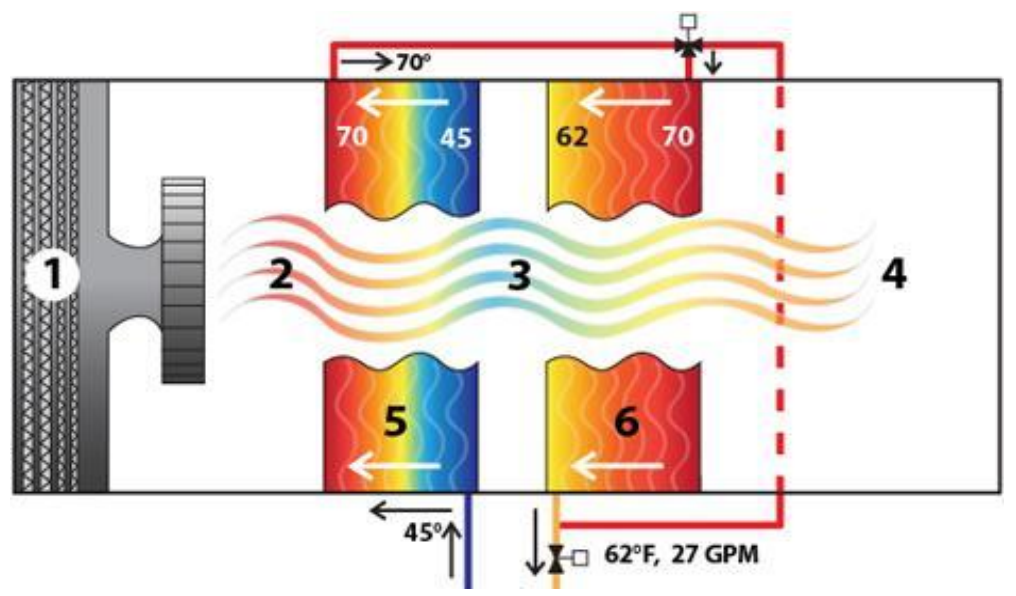

Figure 2: High Efficiency Dehumidification System (HEDS), figure courtesy of ROI.

The conventional air handling unit (AHU) includes a low temperature cooling coil for cooling/dehumidification and a reheat coil to condition the supply air to meet zone set point temperature. The cooling coil is supplied with $45^{\circ} \mathrm{F}$ chilled water and has a leaving water temperature of $55^{\circ} \mathrm{F}$. The reheat coil is supplied with $140^{\circ} \mathrm{F}$ hot water and has a leaving water temperature of $87^{\circ} \mathrm{F}$. Coil flow rates are 70 Gallons Per Minute (GPM) for the cooling coil and 4 GPM for the reheat coil. The base case EnergyPlus model for comparison was developed based on the above specifications provided by ROI (Figure 1).

In the HEDS model, there are also two cooling coils for dehumidification/cooling and reheat. The first cooling coil is supplied with $45^{\circ} \mathrm{F}$ chilled water temperature, but in contrast to the cooling coil in the conventional air handler, the HEDS cooling coil leaving water temperature is much higher at $70^{\circ} \mathrm{F}$. The second coil receives the water from the outlet of the low temperature cooling coil which serves to reheat the supply air stream. In the HEDS case, the air first enters the cooling coil, and then the low temperature dehumidified air enters the reheat coil. This exchanges heat from the $70^{\circ} \mathrm{F}$ water to the $55^{\circ} \mathrm{F}$ airstream. This also reduces the temperature of the water returned to the chiller plant while warming up the air as required to control relative humidity. In case of the conventional system, the return temperature of the cooling coil is higher than the HEDS and due to lower temperature difference along the HEDS chiller, chiller size in HEDS is reduced.

Detailed coil design parameters were not available for the HEDS demonstration unit; therefore, the cooling coil flow rate for HEDS was calculated based on the input parameters given in Figure 1. The cooling coil was modelled based on the inlet and outlet air temperature and inlet and outlet water temperature. Initially, the mass flow rate of chilled water was calculated, then the calculations were rerun iteratively to arrive at a final mass flow rate and outlet air temperature.

EnergyPlus auto-sizing functions were used for calculating the conventional case flow rates and chiller size. For both the baseline (conventional air handler) and the HEDS cases, the air handler was selected as a Variable Air Volume (VAV) system. For the baseline system, the reheat coil was input as coupled with a boiler. For the HEDS model, the reheat coil was input to be supplied from the leaving water of the cooling coil. 
A daytime occupancy (Monday-Friday; 7 am $-6 \mathrm{pm}$ ) with building details and HVAC system with internal load provided in Table 1 and Table 2 were used in the models.

Table 1: Building Construction Details

\begin{tabular}{llll}
\hline S. No. & Parameter & Unit & Values \\
\hline 1 & Wall (U value) & Btu $/ \mathrm{h}-\mathrm{ft}^{2}-\mathrm{F}$ & 0.062 \\
2 & Floor (U value) & Btu $/ \mathrm{h}-\mathrm{ft}^{2}-\mathrm{F}$ & 0.045 \\
3 & Roof (U value) & Btu $/ \mathrm{h}-\mathrm{ft}^{2}-\mathrm{F}$ & 0.044 \\
4 & Window (U value) & Btu $/ \mathrm{h}-\mathrm{ft}^{2}-\mathrm{F}$ & 0.35 \\
5 & Window (SHGC) & - & 0.69 \\
\hline
\end{tabular}

Table 2: HVAC System and Internal Loads

\begin{tabular}{lllll}
\hline S. No. & Parameter & Unit & $\begin{array}{l}\text { Conventional } \\
\text { case }\end{array}$ & HEDS \\
\hline 1 & Chiller capacity & Ton & 28 & 14 \\
2 & COP of chiller & & $5 @ 7.7^{\circ} \mathrm{C}$ & $5 @ 7.7^{\circ} \mathrm{C}$ \\
3 & Airflow rate & $\mathrm{CFM}$ & 10,000 & 10,000 \\
& Supply air set-point & & & \\
4 & temperature & ${ }^{\circ} \mathrm{F}$ & 64.5 & 64.5 \\
& Indoor set-point & & & 75 \\
5 & temperature & ${ }^{\circ} \mathrm{F}$ & 75 & 100 \\
& & & & 20 \\
6 & Occupancy & $\mathrm{No}$ & 100 & 100 \\
7 & Outdoor air & $\mathrm{CFM} / \mathrm{person}$ & 20 & 1 \\
8 & Pressure drop (cooling coil) & $\mathrm{Pa}$ & 250 & 1 \\
9 & Lighting load & $\mathrm{W} / \mathrm{ft}^{2}$ & 1 & \\
10 & Equipment load & $\mathrm{W} / \mathrm{ft}^{2}$ & 1 & \\
\hline
\end{tabular}

For conventional air handler applications, cooling coils are commonly selected with a 350-400 Feet Per Minute (FPM) face velocity. HEDS deploys coils with significantly larger area and operates at a much lower face velocity of approximately 200 FPM; as reported by ROI. At this face velocity, the coil is reported to have an average air-side pressure drop of 0.258 inches of water (as noted from the coil manufacturer's data sheet). To accurately assess the provided performance, a coil designer model ${ }^{1}$ was used to evaluate the air-side pressure drop for a coil with similar geometry. A complete dry operation was assumed, and the following parameters were used to investigate the air-side pressure drop:

${ }^{1}$ University of Maryland (http://www.ceee.umd.edu/consortia/isoc/coil-designer) 
Table 3: Coil Designer Model Input Assumptions

Air-side flow rate $=10,000 \mathrm{cfm}$ Fin type= Plain fin
Tube nominal diameter $=5 / 8$ "

Fin density=12 FPI

Figure 3 depicts the air-side pressure drop for a range of flow depths. The coil air pressure drop noted in the ESTCP Ft. Bragg demonstration is comparable to the simulation results (0.254 in water) at a coil face velocity of approximately $200 \mathrm{FPM}$. While the simulation results align with the reported information, variation in coil air pressure drop may not be accurately characterized in the model and could skew fan energy savings calculations. The air-side pressure drop for a fully wetted coil can be significantly higher than that for a coil observed under fully dry conditions. However, due to inherent uncertainty involved in both experimentation and simulations (due to error in performance correlations), the reported information can be considered sufficiently accurate.

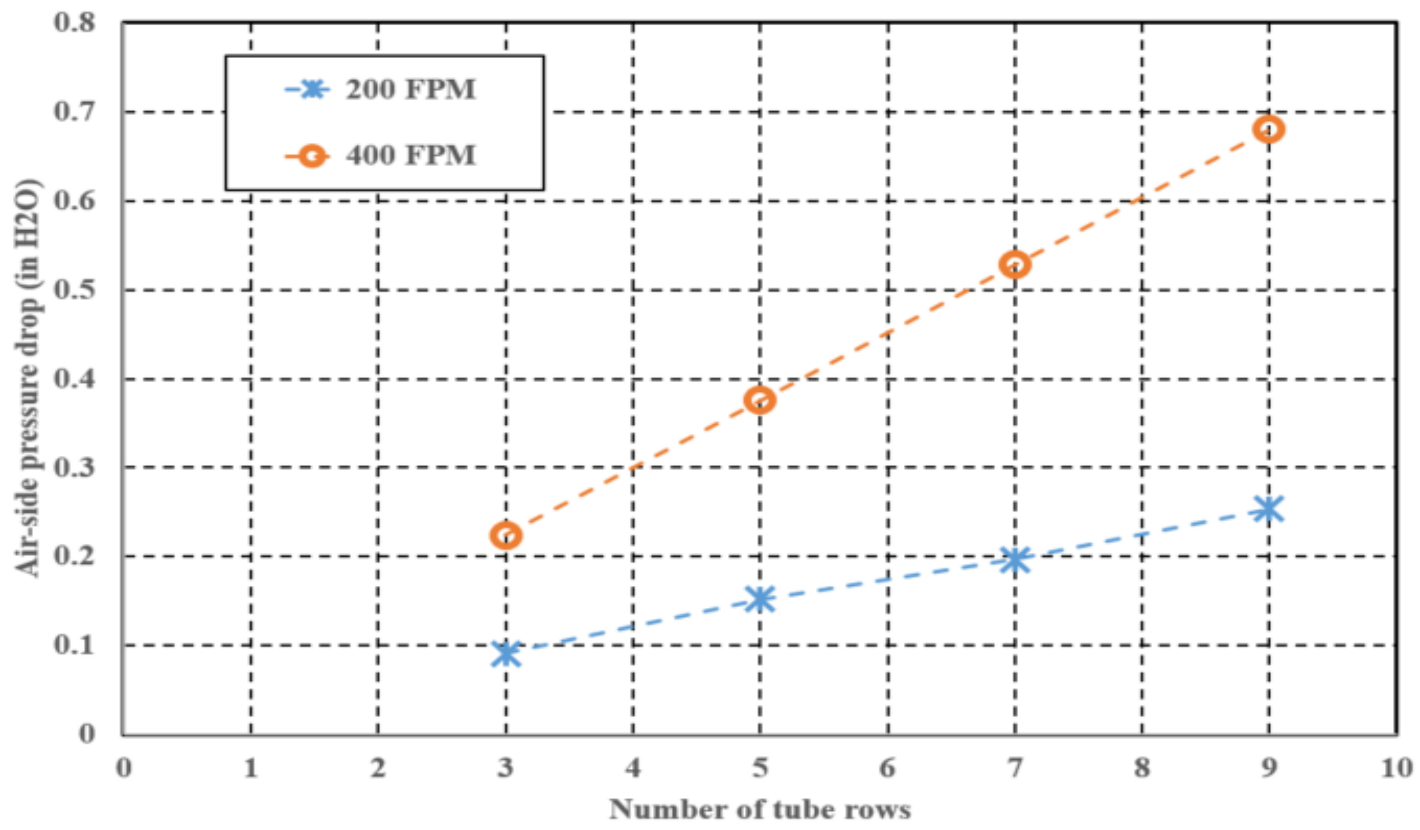

Figure 3: Air-side pressure drop vs. flow depth

To compare the results for different high-humidity climate zones, the building was simulated using EnergyPlus using climate data from two different locations. The envelope and all other input parameters were kept the same for both the locations. The first model was for Fort Bragg Simmons Field having Cooling Degree Days (CDD) of 2007 and Heating Degree Days (HDD) 2760 at $65^{\circ} \mathrm{F}$ base. This location is within ASHRAE climate zone: 3A. The second location was selected as Miami, Florida (CDD: 4459 \& HDD 130 at $65^{\circ} \mathrm{F}$ base - ASHRAE climate zone: 1A).

The HEDS energy models were conducted for two different chiller plant scenarios. One assumed the HEDS installation was a standalone retrofit with no changes to the capacity of the base case chiller plant. The second HEDS model included a downsized chiller capacity to 
match the needs of the HEDS coils. This second model would be more indicative of new construction (with chiller sizing to match the HEDS coils) or of a holistic retrofit where air handlers and the chilled water plant were retrofitted at the same time. 


\section{RESULTS}

Simulations were performed for two different climatic conditions; Fort Bragg Simmons (climate: 3A) and Miami (climate: 1A). Fort Bragg was selected, since the HEDS measurement and verification study was done at this site, and Miami was selected to explore the energy savings potential of HEDS at a different climatic location than the measurement and verification site. Typical Metrological Year (TMY3) weather data from Fort Bragg Simmons air force base and Miami International Airport were used for the simulation. Component level and total HVAC energy consumption of the conventional system and HEDS were compared for the cooling season months.

In the case of HEDS, the chiller supplies the chilled water to the cooling coil, and after transferring the energy from the air to the water, the water (at a higher temperature) enters the heating coil for reheat of the dehumidified air. The innovative coil design and placement utilizes existing system waste energy for air reheat, thereby eliminating the need of externally fed reheat energy as found in conventional systems. The significantly lower water flow rates needed in HEDS is due to the enlarged coil surface area available for heat transfer, reducing the chiller load and pumping energy in the HEDS case. The elimination of externally fed reheat energy, in combination with reduced fan energy, can result in HVAC energy savings from $16 \%$ to $49 \%$ depending on climate conditions and whether the building chiller capacity is downsized in conjunction with HEDS installation. 


\subsubsection{Energy savings analysis for Fort Bragg - HEDS with retrofit chiller}

Figure 4 shows the monthly variation of ambient temperature and relative humidity at Fort Bragg. Only months that require cooling, April-September, were used for HVAC energy savings calculation.

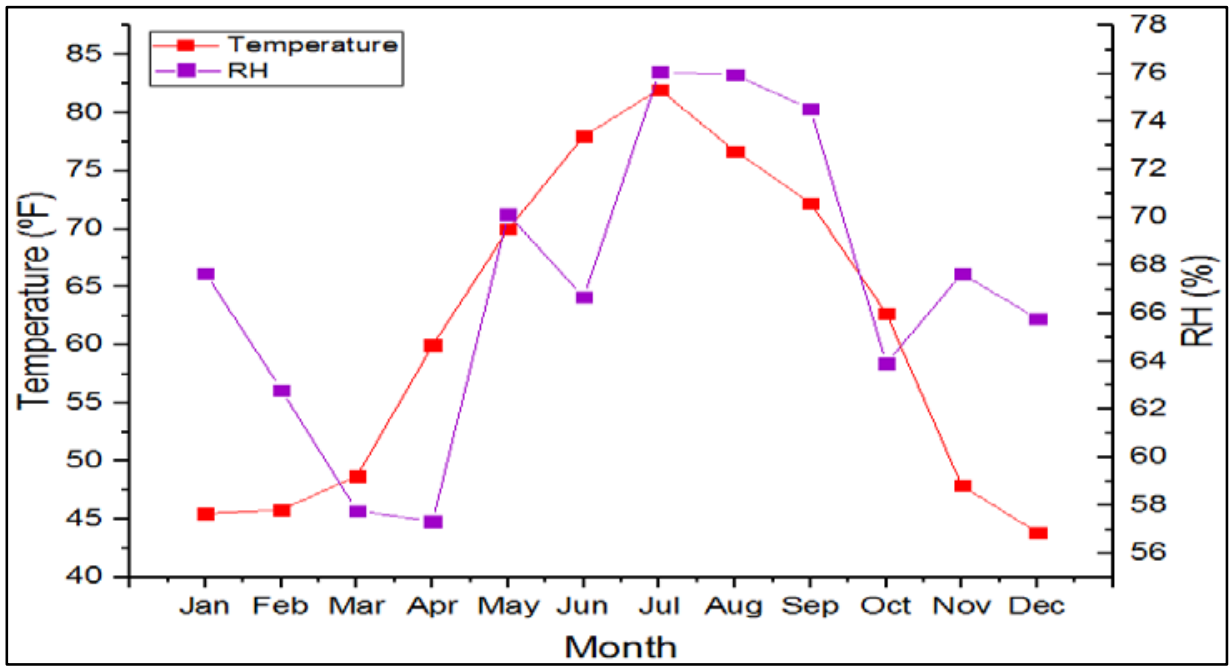

Figure 4: Monthly ambient temperature and relative humidity, Fort Bragg Simmons Field

Figure 5 shows the comparison of annual HVAC energy consumption of conventional system and HEDS. HEDS saves around 37\% of HVAC energy for Fort Bragg. In case of HEDS, the main energy savings comes from eliminating the need for externally fed (e.g. boiler supplied) reheat and due to the reduction in the size of chiller.

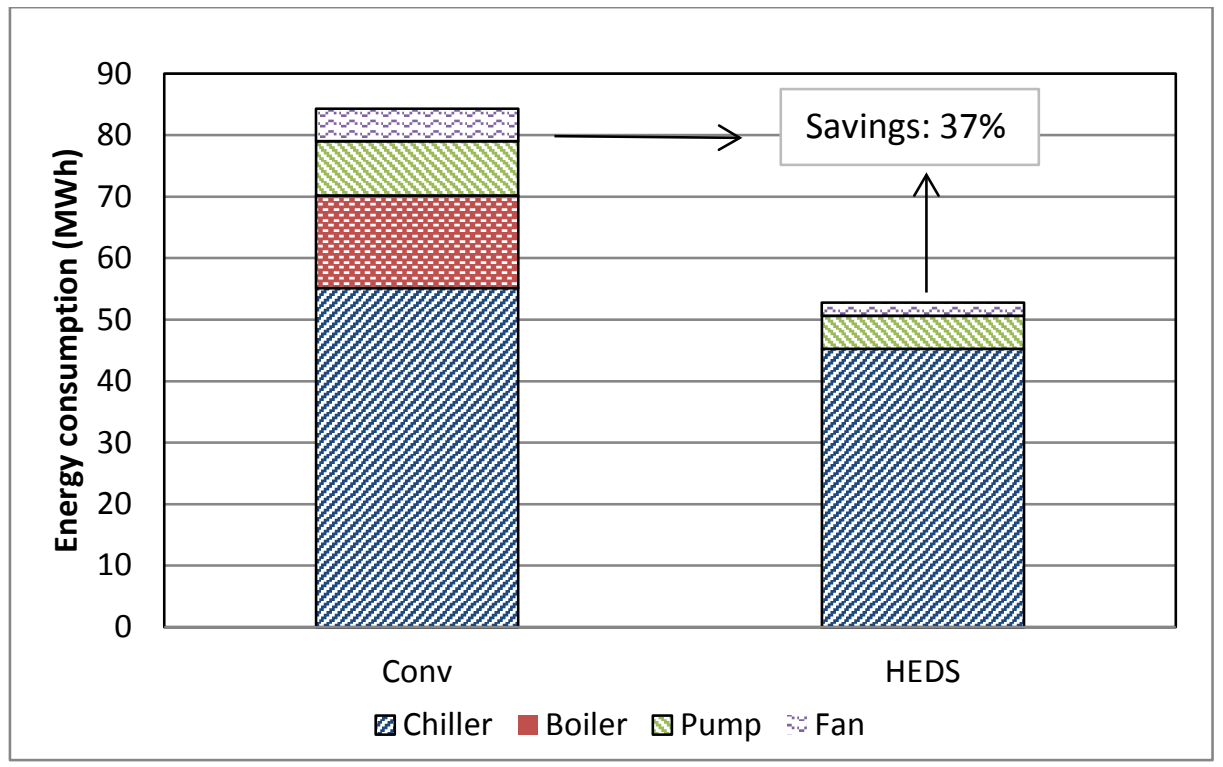

Figure 5: Comparison of energy consumption for conventional system and HEDS, Fort Bragg 
Figure 6 shows the monthly comparison of chiller energy consumption for conventional system and HEDS for cooling months.

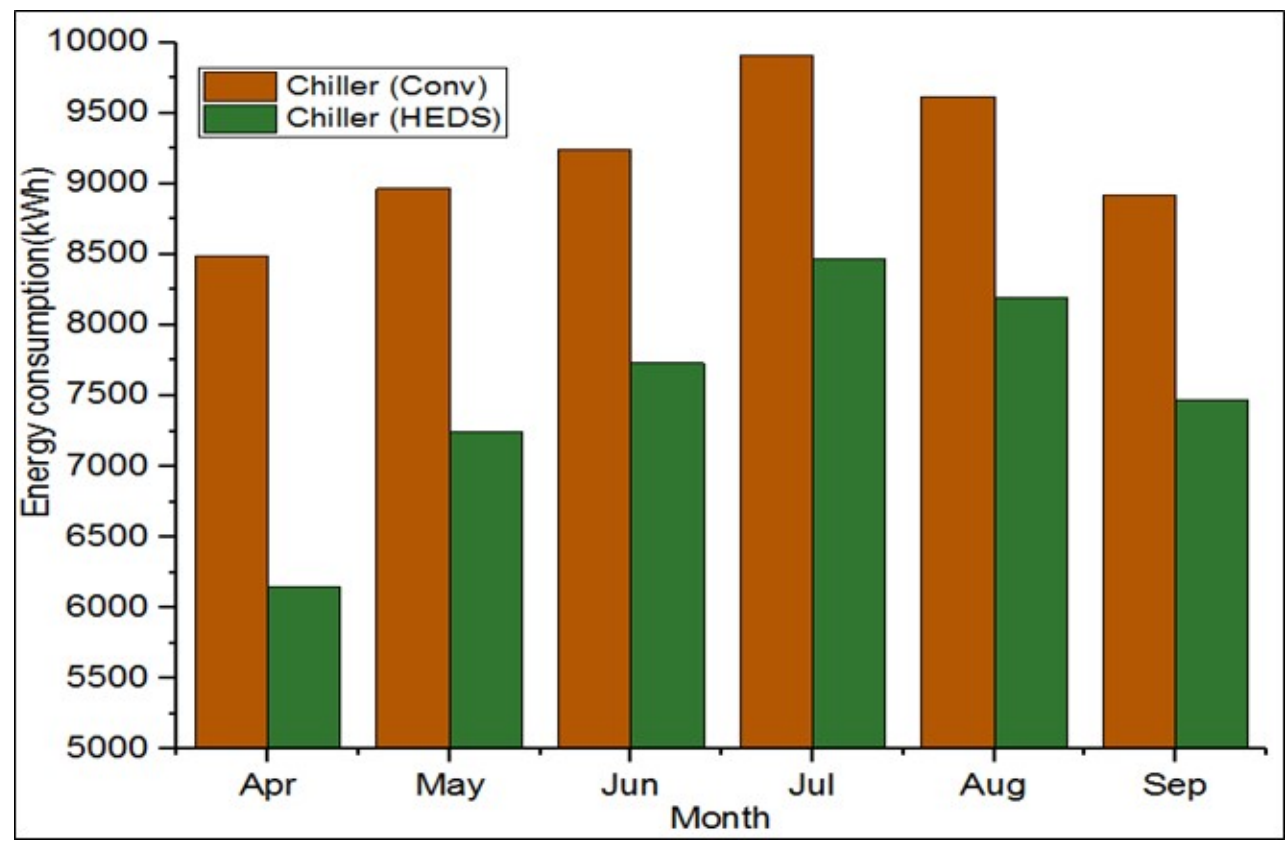

Figure 6: Monthly chiller energy consumption for cooling months, Fort Bragg

Figure 7 shows the variation of fan energy for the conventional system and HEDS. Pressure drop for the cooling coil in conventional system was assumed as $250 \mathrm{~Pa}$ and it is reduced to $100 \mathrm{~Pa}$ in case of HEDS, as per manufacturer's description. For the simulation period 59\% fan energy saving has been achieved in case of HEDS compared to conventional system.

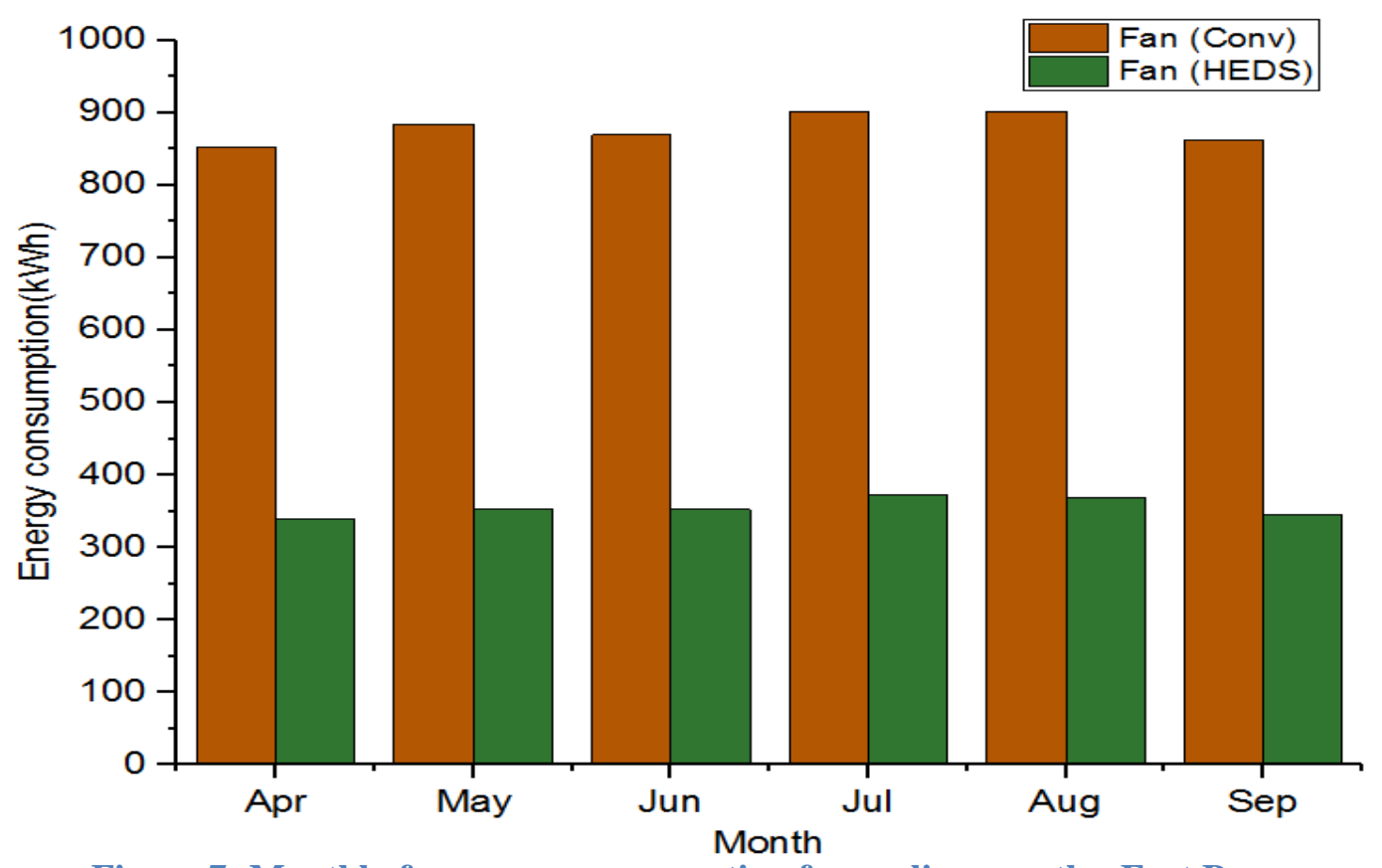

Figure 7: Monthly fan energy consumption for cooling months, Fort Bragg 
Figure 8 shows the variation of cooling coil inlet temperature, cooling coil outlet temperature, heating coil outlet temperature and relative humidity in the zone for the peak day (July 21) for the HEDS.

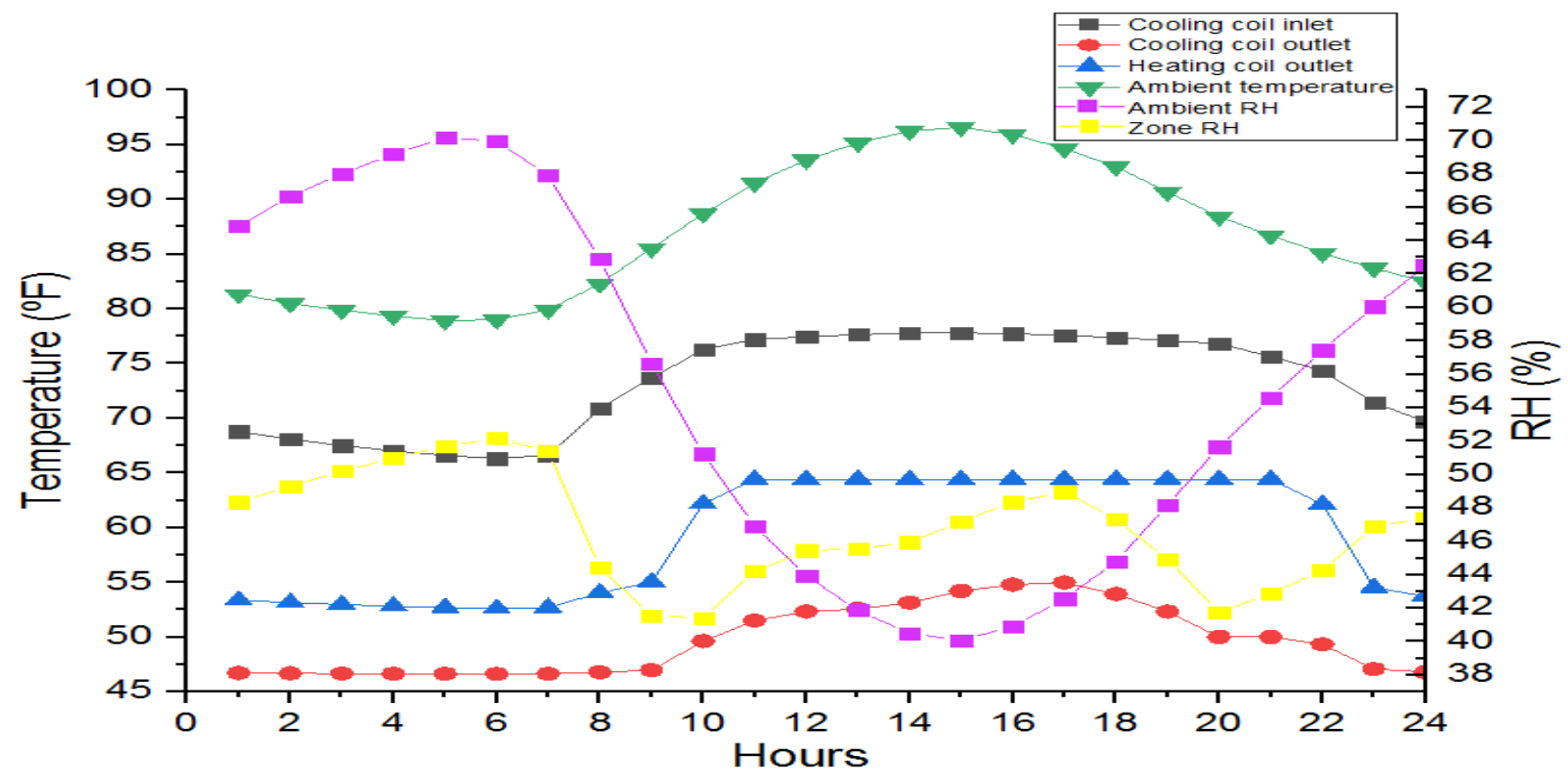

Figure 8: Coil Water Temperatures and space RH for a peak day at Fort Bragg

Figure 9 shows the comparison of total energy consumption for conventional system and HEDS. Total energy consumption is the sum of chiller energy, pumping energy, fan energy and reheat energy.

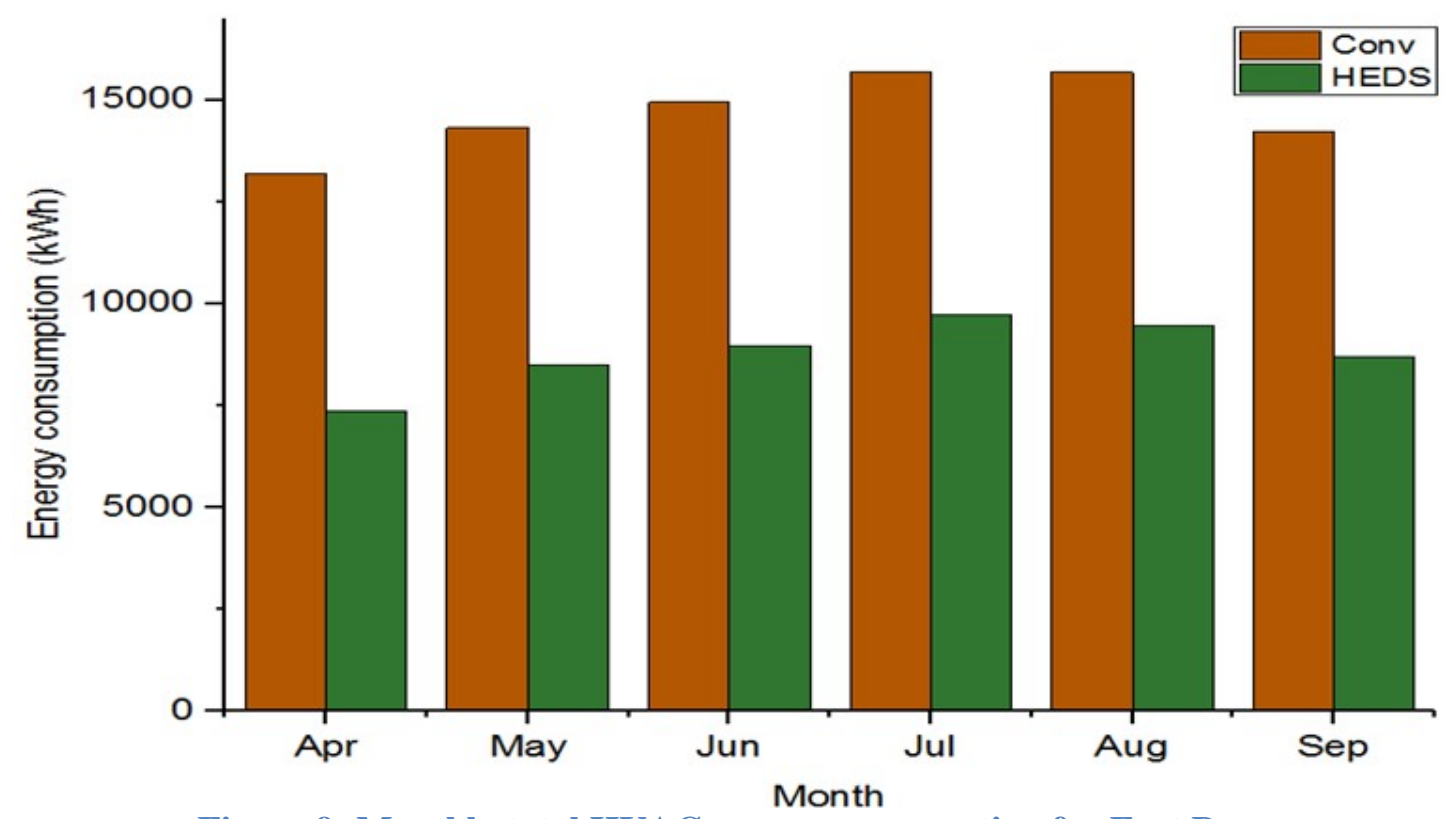

Figure 9: Monthly total HVAC energy consumption for Fort Bragg 


\subsubsection{Energy savings analysis for Fort Bragg - HEDS with basecase chiller}

The HEDS model was also analyzed as a standalone (air handler only) retrofit, with the existing basecase chiller capacity remaining the same. Figure 10 and Figure 11 show the overall cooling energy savings and monthly chiller energy consumption comparison for a HEDS air-handler only retrofit case Fort Bragg. The existing chiller would be operating at a lower load condition and therefore at a point lower on its unit efficiency curve. The HEDS would still be able to save HVAC energy for April-Sept on the order of $16 \%$. In this case, the savings are driven by the elimination of reheat energy and reduction in fan energy, as the HEDS coils have much lower air pressure drop than the basecase system.

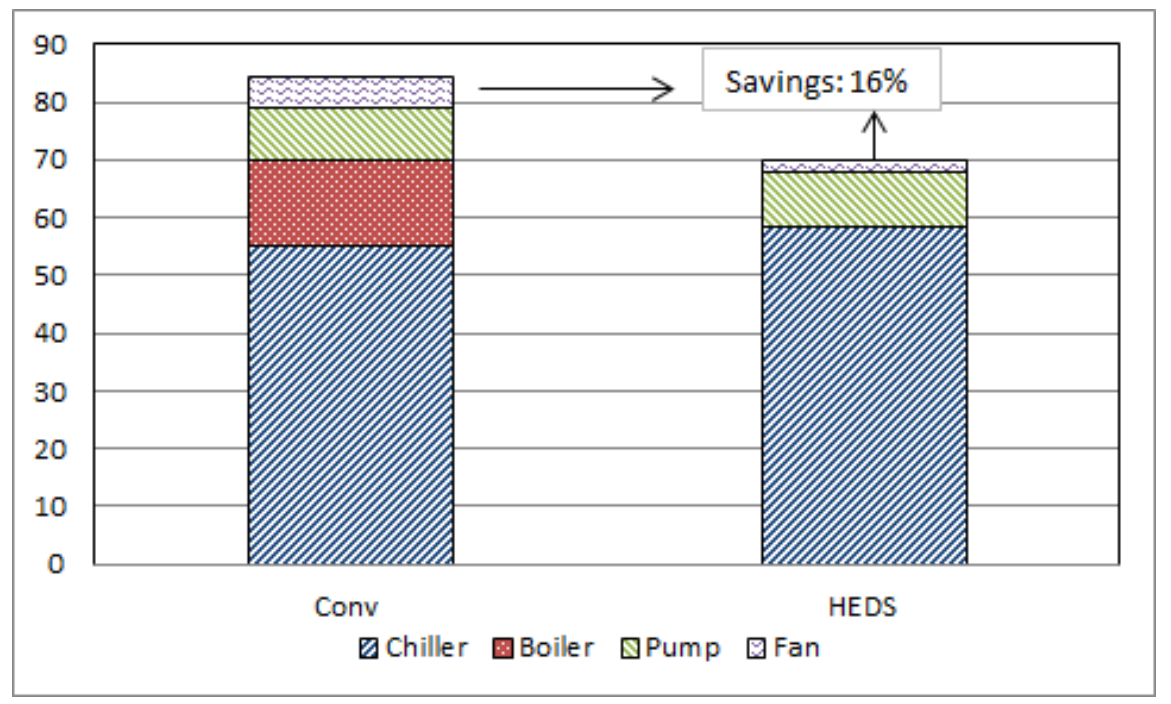

Figure 10: Comparison of HVAC energy consumption, retrofit case Fort Bragg

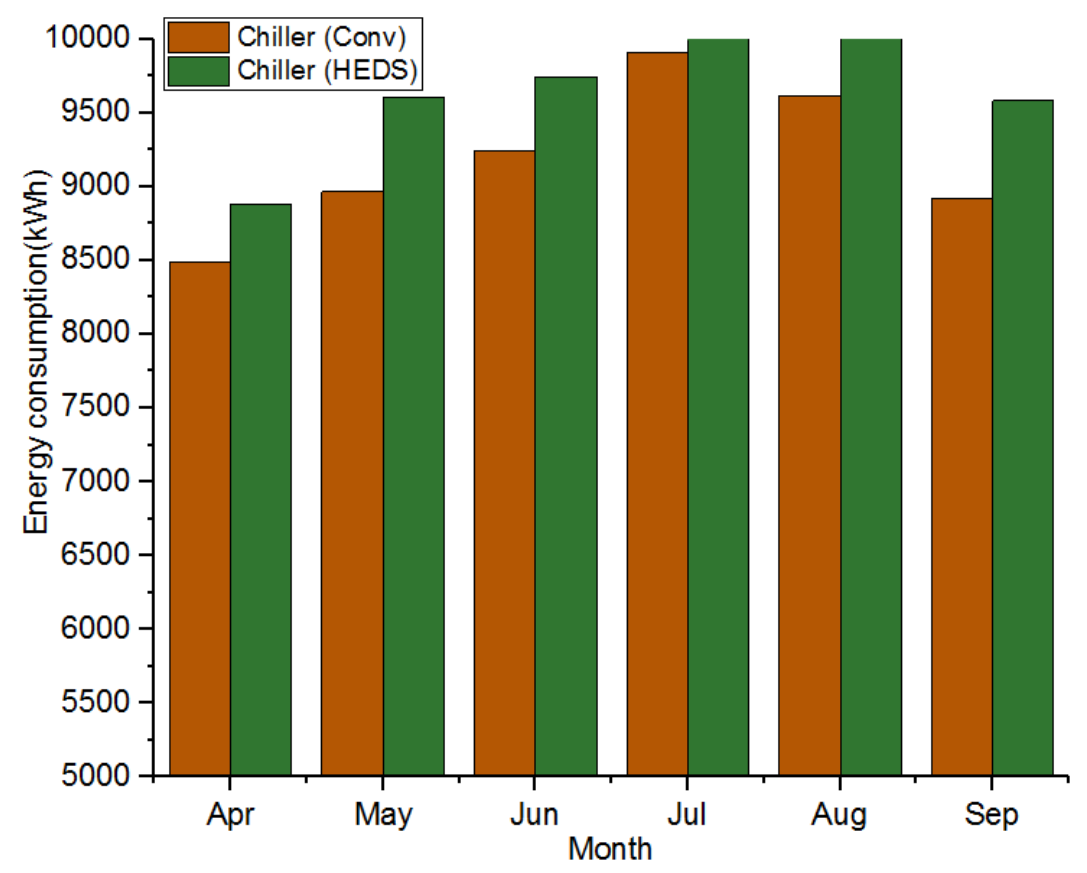

Figure 11: Monthly chiller energy consumption for cooling months, retrofit case Fort Bragg 


\subsubsection{Energy savings analysis for Miami - HEDS with retrofit chiller}

Simulations study was conducted for Miami, a hot climate to determine the performance of HEDS in a much hotter and humid climate than Fort Bragg where the measurement and verification of HEDS was done. Figure 10 shows the monthly variation of the ambient temperature and the relative humidity for Miami.

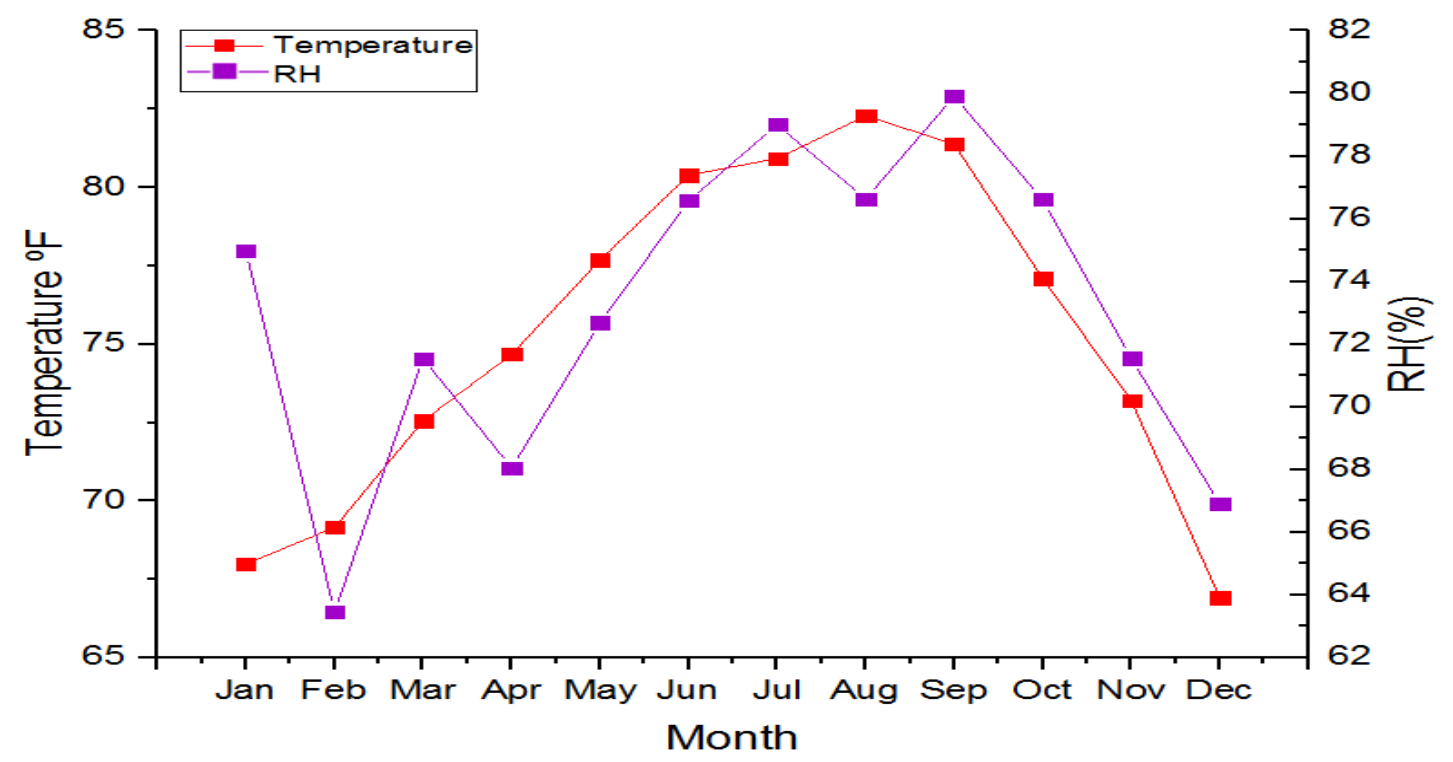

Figure 12: Monthly ambient dry bulb temperature and RH for Miami

Figure 11 shows the comparison of HVAC energy consumption for a conventional system and a HEDS system during cooling months. HEDS saves $49 \%$ of HVAC energy in Miami. Like the Fort Bragg model, the savings resulted both due to reduction in chiller size and elimination of additional reheat energy. The energy savings is greater than that at Fort Bragg due to the higher humidity load and longer cooling season in Miami.

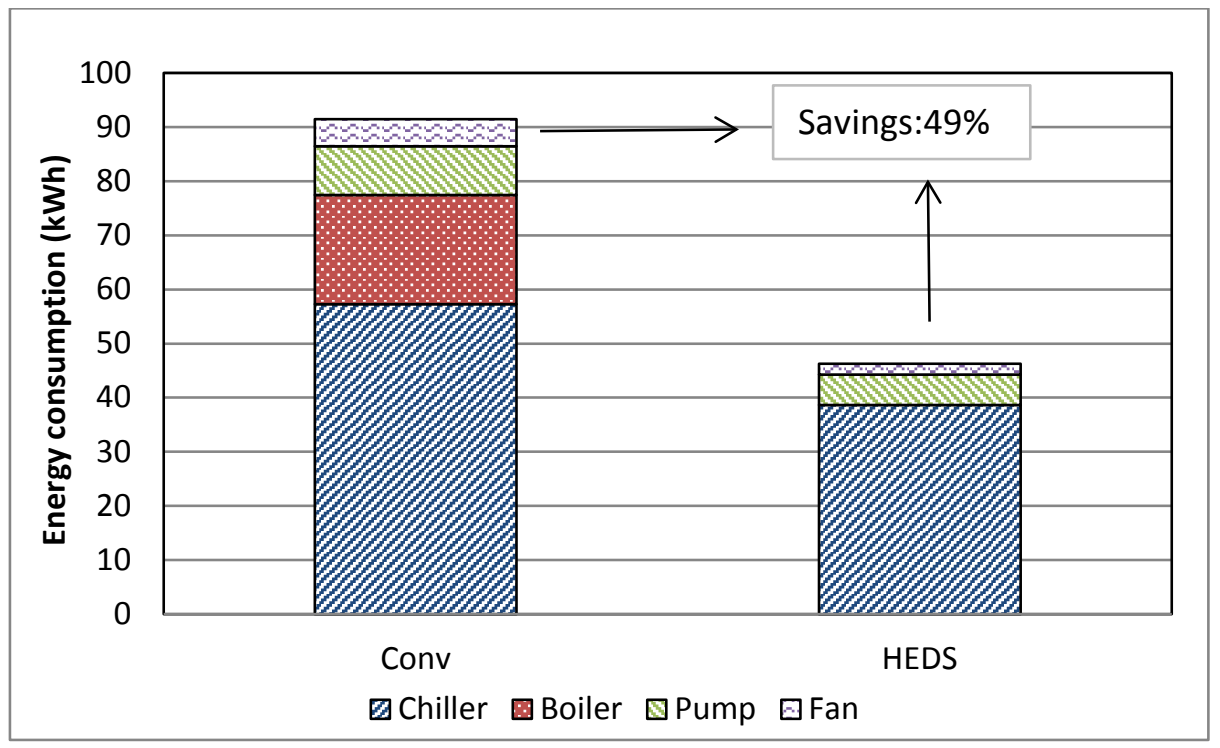

Figure 13: Comparison of energy consumption for cooling months, Miami 
The chiller energy consumption for conventional system and HEDS is shown in Figure 12.

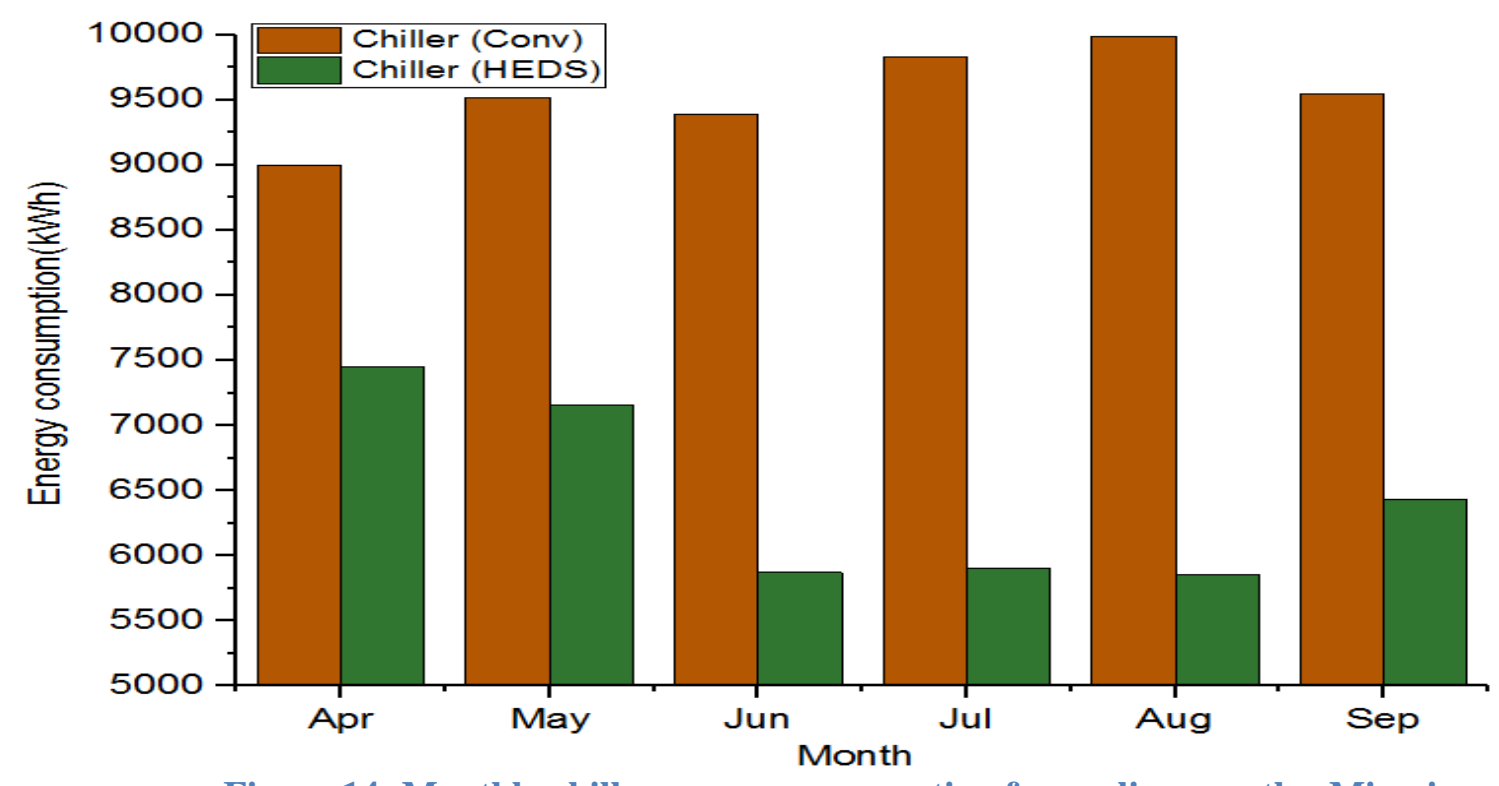

Figure 14: Monthly chiller energy consumption for cooling months, Miami

Figure 13 shows the comparison of fan energy consumption for the conventional system and HEDS. Due to lower pressure drops in the HEDS cooling coil compared to the conventional cooling coil, fan energy savings of up to $60 \%$ can be achieved.

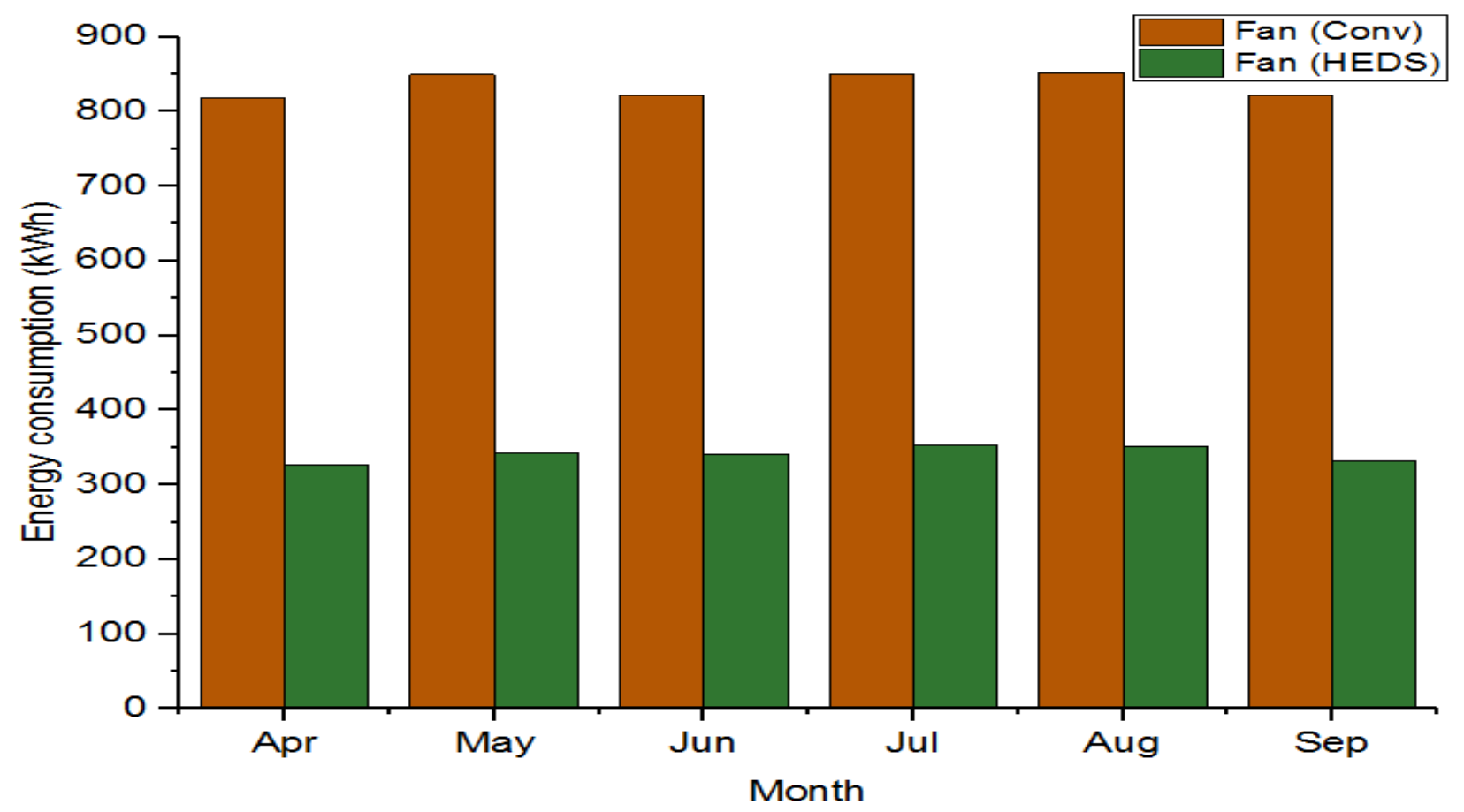

Figure 15: Monthly fan energy consumption for cooling months, Miami 
Figure 14 shows the comparison of cooling coil inlet, outlet water temperature, heating coil water outlet temperature and $\mathrm{RH}$ of space for HEDS on peak day.

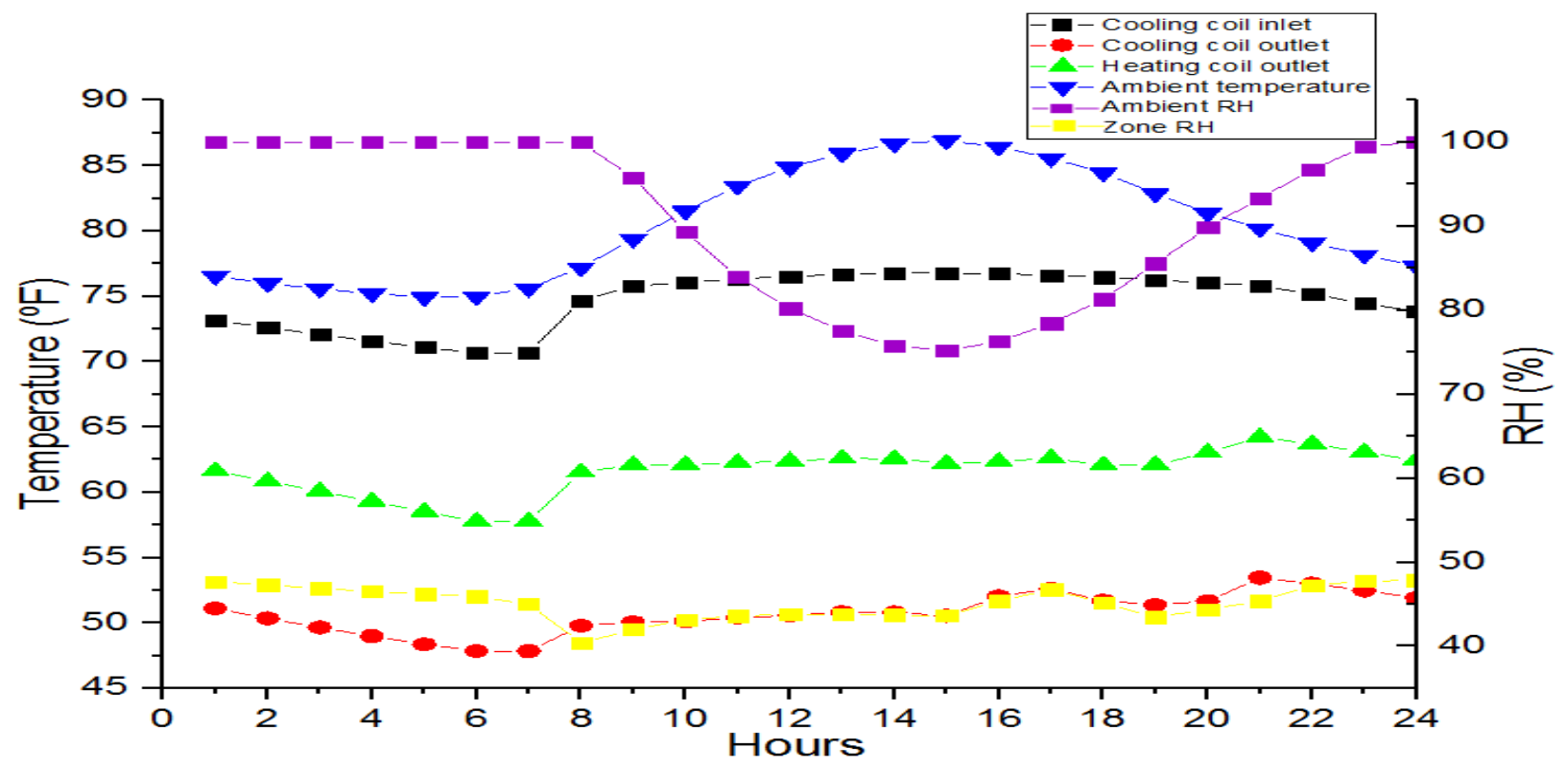

Figure 16: Coil temperatures and space RH for HEDS on a peak day (July 21) for Miami

Figure 15 shows the comparison of total HVAC energy consumption for the conventional system and HEDS for summer season.

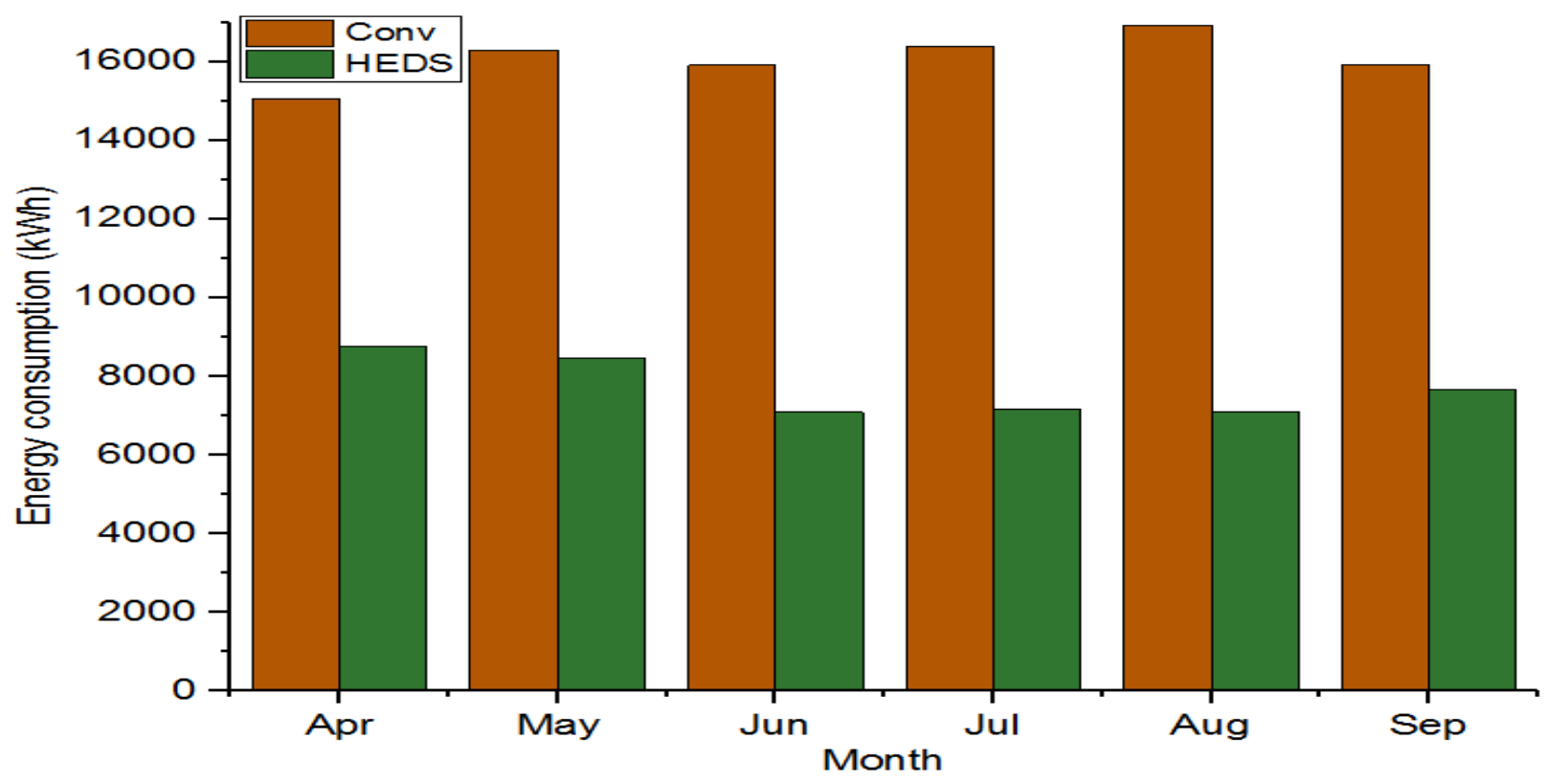

Figure 17: Monthly total HVAC energy consumption for Apr-Sept, Miami 


\subsubsection{Energy savings analysis for Miami - HEDS with basecase chiller}

Figure 18 and Figure 19 show the overall cooling energy savings and monthly chiller energy consumption comparison for a retrofit case in Miami with a standalone HEDS air handler retrofit. The chiller was assumed to remain the same size. The HEDS would still be able to save on the order of $31 \%$ of HVAC energy. The savings are mainly due to the elimination of reheat energy and reduction in fan energy.

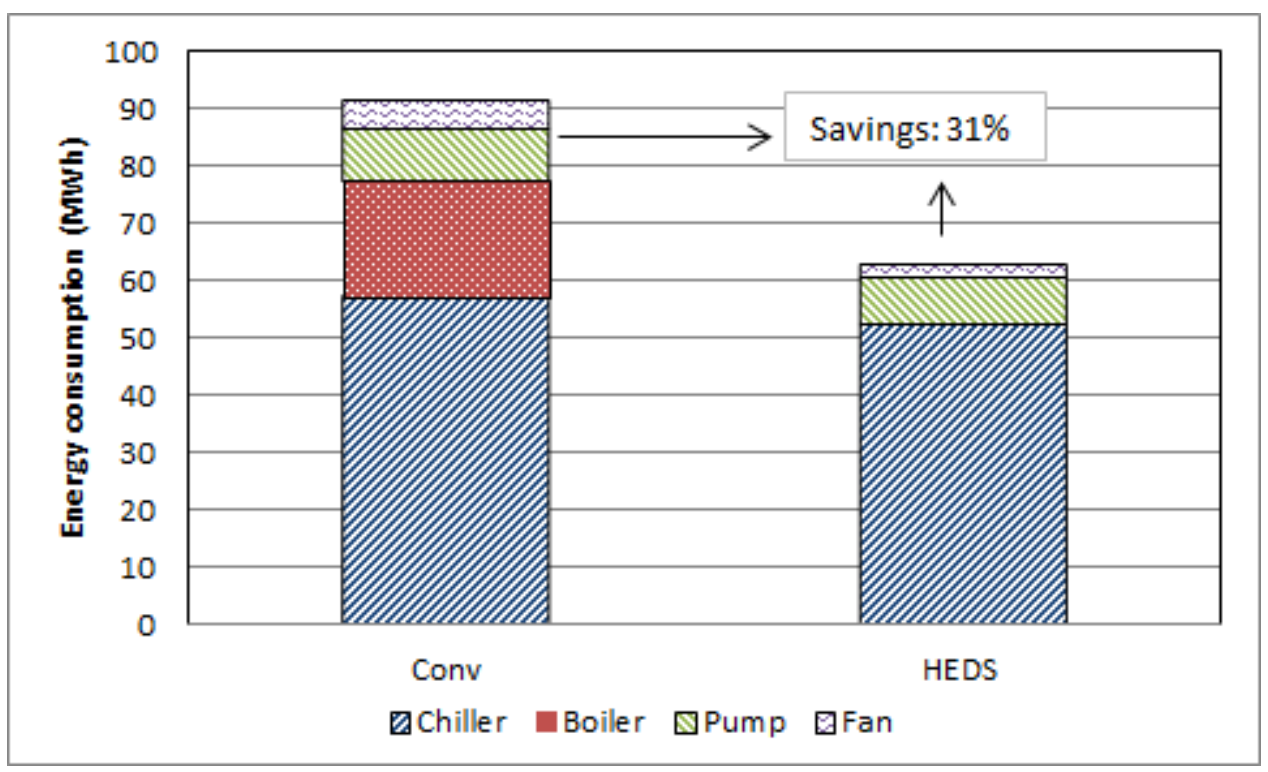

Figure 18: Comparison of energy consumption for cooling months for a retrofit case, Miami

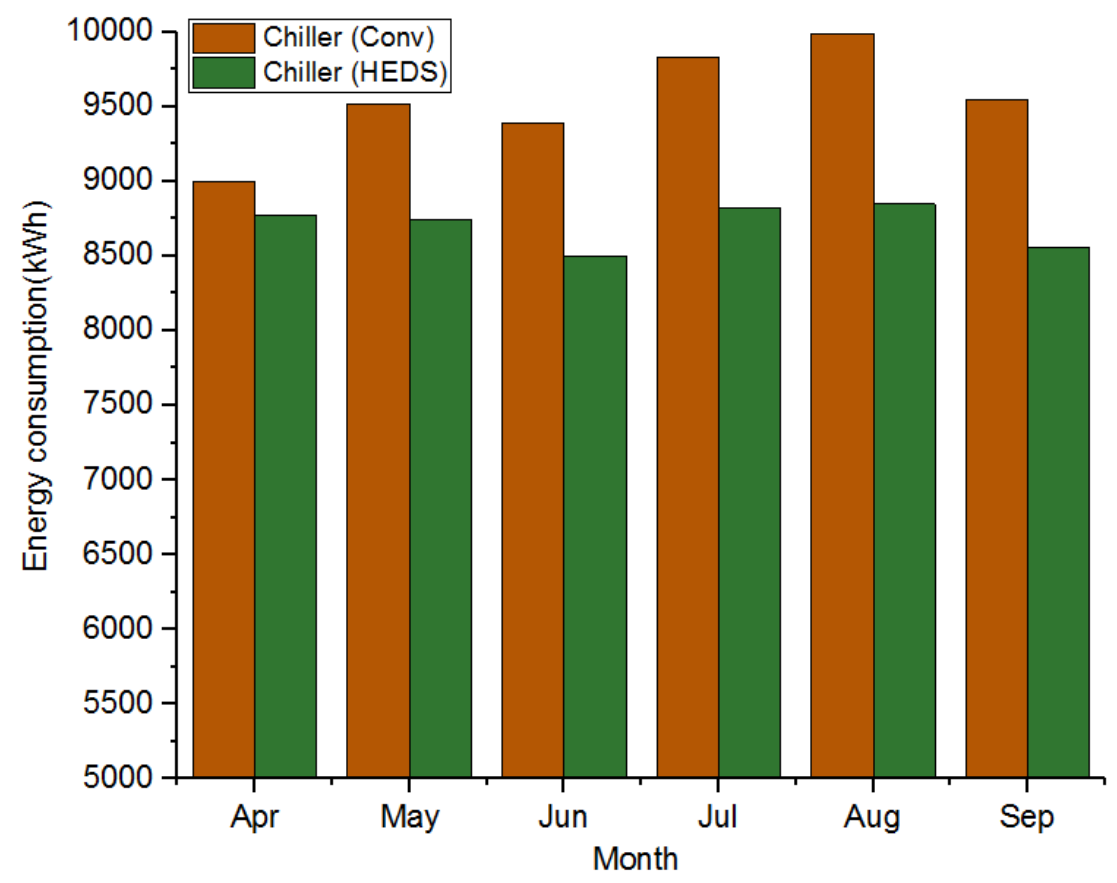

Figure 19: Monthly chiller energy consumption for cooling months for a retrofit case, Miami 


\section{DISCUSSION}

The simulations for a0,000 sf building show the HEDS approach has the potential to save HVAC energy use as compared to convention system having reheat from an external source (e.g. boiler). Simulations at two different high-humidity climate locations show that the HEDS approach, coupled with chiller right-sizing to a reduced capacity, may realize up to 49\% HVAC energy savings in comparison to a case with a conventional air handler and coil arrangement. As a standalone retrofit (meaning a HEDS-only air handler retrofit with no change to the chiller), the savings would still be appreciable with savings up to $31 \%$.

It is noted the detailed coil geometry parameters were not available, therefore a coil modeling tool was used to develop coil parameters to be used in the energy model. The energy performance of this modelled coil was compared to a basecase coil identified by ROI. Due to variations in coil parameters from a modelled coil to an actual manufacturer's coil, the he HVAC savings for an installed HEDS system could differ significantly from the savings presented in this simulation study. A detailed calibrated study or side-by-side comparison of HEDS with a conventional case would provide more accurate energy savings potential.

The HEDS approach shows the potential to save energy in several aspects of the HVAC system performance including fan energy, chiller plant energy and boiler plant energy. This simulation study was based on a building using calculated component sizes. The models represent idealized installation conditions which might not be completely realized in a field installation. An example of this variation is the modelled coil air pressure drop which may vary from a final selected coil's pressure drop.

This analysis addressed HVAC energy use only and did not include a financial analysis of simple payback or return on investment. In addition to installed costs and utility costs, another consideration is whether a potential site has space available to employ a HEDS air handler (which in comparison to a conventional air handler selection will have a larger air handler footprint due to the larger coil face area).

This modeling analysis also included a simplified model to assess the full system benefit of the HEDS approach if the chilled water plant were optimized in terms of downsizing to match the reduced chilled water needs at the HEDS coil. This represents an idealized case, where funds are available to address the system improvements holistically from air handler to chiller. Overall system savings would be reduced if chiller optimization were to be excluded due to financial constraints. 